\title{
Lateral Meristems Responsible for Secondary Growth of the Monocotyledons: A Survey of the State of the Art
}

\author{
Joanna Jura-Morawiec ${ }^{1,4} \cdot$ Mirela Tulik $^{2}$. \\ Muhammad Iqbal ${ }^{3}$
}

\author{
${ }^{1}$ Polish Academy of Sciences Botanical Garden - Centre for Biological Diversity Conservation in Powsin, \\ Prawdziwka 2, 02-973 Warsaw, Poland \\ ${ }^{2}$ Department of Forest Botany, Warsaw University of Life Sciences - WULS, Nowoursynowska \\ 159, 02-776 Warsaw, Poland \\ ${ }^{3}$ Department of Botany, Jamia Hamdard (Hamdard University), Tughlaqabad, New Delhi 110062, India \\ ${ }^{4}$ Author for Correspondence; e-mail: j.jura@gazeta.pl
}

Published online: 4 April 2015

(C) The Author(s) 2015. This article is published with open access at Springerlink.com

\begin{abstract}
This review highlights key historical works and the recent research on the monocot lateral meristems. It discusses the terminological issues (elucidating the terminological inconsistency found in the literature concerned), origination of secondary meristems, their morphology and characteristic features of the derivative tissues. Also the monocot cambium response to hormonal and gravitational stimuli is discussed. The summarized inputs in the present note are believed to renew interest in this field, which is important for a more comprehensive understanding of the abnormal secondary growth in the monocotyledons.
\end{abstract}

Keywords Monocotyledons · Etagen meristem · Monocot cambium · Storied cork

\section{Introduction}

Occurrence of secondary growth due to the activity of two laterally positioned meristems, viz. the vascular cambium and the phellogen (cork cambium) is a common feature of the gymnosperms and dicotyledons. Among the monocotyledons, secondary growth is not so common and is realized by the activity of peculiarly different meristems. The presence of the secondary vascular system has been recognized within 22 genera only (Rudall, 1995) belonging to the Asparagales (Seberg et al., 2012), whereas a protective tissue of secondary origin has been identified in Zingiberaceae, Bromeliaceae, Commelinaceae and Arecaceae (Schoute, 1902; Krauss, 1949; Tomlinson, 1961).

While progressively more is known about the secondary growth common to most vascular plants, the abnormal secondary thickening of monocots remains understudied. As was pointed out by Carlquist (2012) and earlier workers (Tomlinson \& Zimmermann, 1967), the non-monocot angiosperms generally form an easier experimental material. Therefore, we know much more about their anatomy and physiology than of the monocots. The apparent lack of interest in research on the monocot 
secondary tissues may also be connected possibly with their less commercial significance. The major models for the current research of secondary growth in angiosperms are Arabidopsis thaliana and the species of the genus Populus (Ursache et al., 2012). The latter is important in the boreal forests and in temperate plantations for the pulp and paper production. Similarly, Quercus suber, the main source of commercial cork, is of particular interest with regard to its protective tissue formation (e.g. Ramos et al., 2013). Due to the fact that some of the monocots with secondary growth also supply economically important products (like dragon's blood) and belong to the vulnerable species, e.g. Dracaena cinnabari or D. draco (IUCN, 2014) the studies concerning their growth pattern are pivotal to our understanding of the process of their development. Moreover, it may be helpful in practical breeding of species like D. fragrans or D. sanderiana which are popular ornamental pot plants and have the ability to improve the indoor air quality by removing air pollutants (Wolverton et al., 1989; Treesubsuntorn \&Thiravetyan, 2012).

It is known that the meristems responsible for secondary growth in monocot plants differ from the cambia of the gymnospermous and dicotyledonous species. However, except for some preliminary information on their origin and activity, little is known about their structure and behavior. In this review attention is focused on the secondary thickening of stems only although a reference has been made to roots in the case of Dracaena (Tomlinson \& Zimmermann, 1969). We will discuss in particular (a) the terminological issues, (b) development of secondary meristems, (c) their morphology, (d) the characteristics of derivative tissues, and (e) the response of monocot cambium to hormonal and gravitational stimuli. This summary of information on the secondary growth in monocotyledons can initiate discussion on the issues that have so far been enigmatic.

\section{Terminology}

The elusive nature of the lateral meristems in the monocotyledons has been posing problem with the application of relevant terminology. The literature is fraught with synonyms referring (a) to the meristem producing the secondary vascular tissues, e.g. the thickening ring (Scott \& Brebner, 1893), the Etagencambium (Schoute, 1902), the meristematic zone (Arber, 1925), the secondary thickening meristem (Clowes, 1961), the anomalous cambium (Stone, 1970), the vascular cambium (Zimmermann \& Tomlinson, 1970, 1972), the accessory cambium (Rastogi, 2009), the cambium-like zone (Beck, 2010) and the monocot cambium (Carlquist, 2012), as well as (b) to the meristem producing secondary protective tissues, e.g. the Etagenmeristem (Philipp, 1923; Tomlinson, 1961), the storied meristem (Fahn, 1967), and the storied phellogen (French \& Tomlinson, 1981). However, in the case of secondary protective tissues the meristem itself is rarely distinguished, and normally the term storied cork is used, covering both the meristematic cells and their derivatives.

The German term etagen and its English counterpart storied that appear frequently in descriptions of the monocot secondary growth, have been used to underline the temporary form of the monocot meristems. These are zones of cells that do not form a continuous radial file in transverse view due to lack of permanent initials (Schoute, 1902). However, various series, tiers, rows, bands or the so-called stories of cells with 
only limited radial length become visible in transverse plane (Fig. 1a). It is clear from the above that, currently, one and the same term etagen/storied is being applied to two different conditions, depending on the plant group. In the monocotyledons, the term etagen/storied relates to the arrangement of cells of the lateral meristem (etagen meristem) and the cork tissue (storied cork) as visible in transverse plane (Cheadle, 1937; Rudall, 1991; Donoghue, 2005; Evert, 2006; Verma \& Khosa, 2012), while in the dicotyledons, it refers to the stratified arrangement of cells of the vascular cambium (Fig. 1b) and the cambium-derived vascular tissues (secondary phloem and secondary xylem) as seen in tangential plane (Bailey, 1923; den Outer, 1986; IAWA, 1989). In the monocotyledons the cork cells do not form tiers in the tangential view (Fig. 1c), likewise the cells of the monocot cambium (Fig. 1d). The discrepancy in the two meanings of the given term is striking. However, both the usages are already well established in the literature and replacement of 'storied cork' by a more appropriate term like 'rowed cork' may be difficult.

The peculiar monocot cambium produces secondary growth that can be considered as a true secondary growth (Fisher, 1973; Fisher et al., 1974; DeMason, 1994) because it is the product of divisional activity of a secondary meristem (Tomlinson \& Zimmermann, 1969 and earlier workers).

\section{The Monocot Vascular Cambium}

\section{Origin of the Meristem}

Here, the meristem will be named as secondary thickening meristem (STM) or the monocot cambium, as these two terms most frequently appear in the current literature. The monocot cambium is not to be regarded in any way as a vestige of the initial/ vascular cambium that is presumed to have existed in the common lignophyte ancestor of the traditional dicotyledons and monocotyledons (Rudall, 1991; Carlquist, 2012). Ontogenetically, the monocot cambium originates from the primary thickening meristem (PTM), which is a region of actively dividing meristematic cells, located around the apical meristem and extending down the periphery of the stem, where this
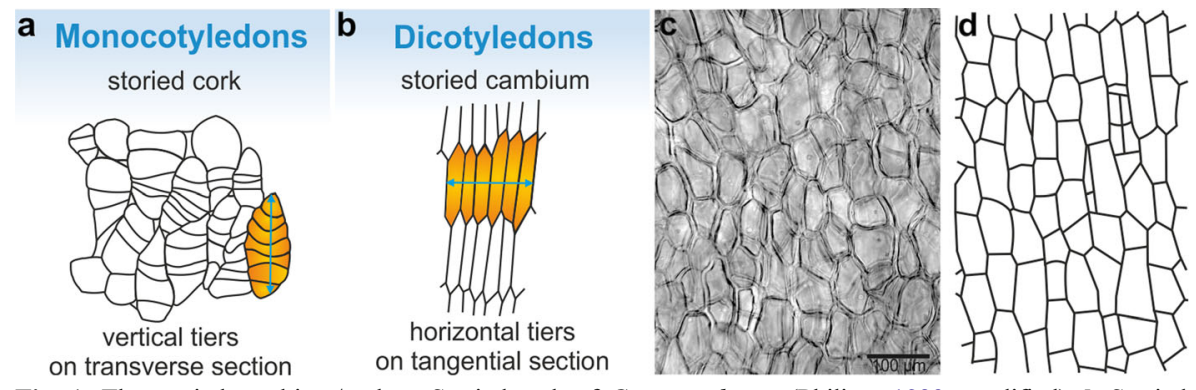

Fig. 1 The storied cambium/cork. a Storied cork of Curcuma longa (Philipp, 1923, modified); b Storied cambium of Laburnum sp. (Majumdar, 1941, modified); c Tangential section of storied cork of Dracaena draco stem; d Scheme of tangential section of monocot cambium in the stem of Cordyline terminalis (Philipson et al., 1971, modified) 
continuation of PTM is referred to as STM. Thus, the occurrence of PTM is a prerequisite for differentiation of the STM/monocot cambium (Stevenson \& Fisher, 1980; DeMason \& Wilson, 1985). According to Diggle and DeMason (1983b), the transition of primary meristem into secondary meristem in the monocotyledonous species is analogous to the transition of procambium to vascular cambium in the woody dicotyledonous stem. On the basis of a detailed study of Yucca whipplei, covering the histology (Diggle \& DeMason, 1983a, b) and audiography (DeMason \& Diggle, 1984) observations, it was concluded that the PTM and the monocot cambium (referred to by them as STM) are ontogenetically related to each other and "function as a single entity during the growth and development of the vegetative stem". This idea found support from the subsequent observations on Cordyline terminalis (DeMason \& Wilson, 1985). Earlier, Fahn (1967) also pointed out that if these two meristematic tissues are present in one plant, they could be two developmental phases of the same meristem. Diggle and DeMason (1983a, b) held that the PTM and the STM are histologically similar and are recognizable as a region of radially flattened cells arranged in anticlinal files. A distinction between these meristems was possible usually because of the cell arrangement in derivative tissues, especially those within the vascular bundles. Formation of the amphivasal vascular bundles indicates the presence of the monocot cambium and the commencement of the secondary growth (Diggle \& DeMason, 1983b). However, the transitional state is confusing even within the vascular bundles; therefore, when distinction between the PTM and the STM was not possible, the term thickening meristem was used (DeMason \& Wilson, 1985). Careful structural studies of the monocot cambium could help to check whether additional criteria can be established for a better identification of the secondary meristem.

\section{Cambial Morphology and Cell Structure}

Anatomical studies of the monocot cambium have been only few and the information about its cellular composition is limited. It is known that the monocot vascular cambium is rayless and consists of only one type of cells that look rectangular, fusiform or polygonal in shape. To date, only two photographs, which depict the arrangement of cambial initials in the tangential section, have been published (Cheadle, 1937; Philipson et al., 1971). They present a somewhat nonstoried arrangement of cells (Fig. 1d). In the transverse view, this meristem is described as a multi-layered zone of radially flattened cells, that possess small radial dimension and are tangentially elongated (Fig. 2a). They produce files of derivatives by means of successive periclinal divisions, which is also clearly visible in radial section (Fig. 2b).

Long ago, Cheadle (1937) opined with reference to the monocot cambium that neither an exact location nor a convincing description of the cambial initials was available in the literature, and unfortunately this statement is considerably valid even today. Further, the ultrastructural studies of the monocot meristems seem to have been confined to a single report on Aphyllanthes monspeliensis, demonstrating that the active cambial cells are highly vacuolated with protein bodies seen occasionally in the vacuoles (Chakroun \& Hébant, 1983). 


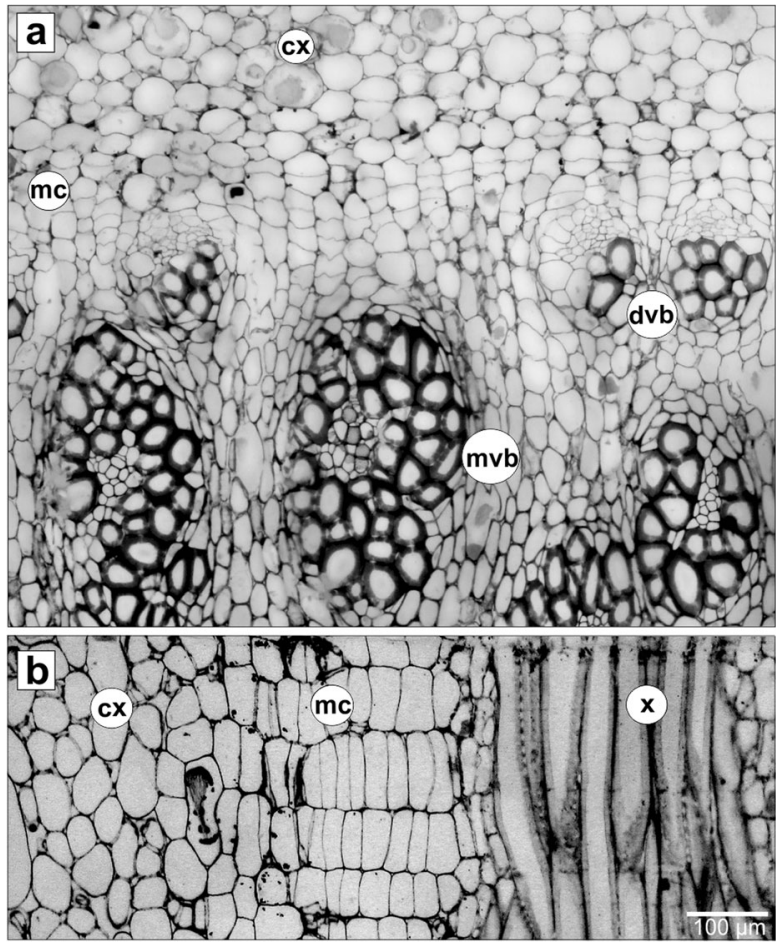

Fig. 2 The monocot cambium and its derivative tissues in Dracaena draco stem. a Transverse and $\mathbf{b}$ radial sections. $c x$ - cortex, $m c$ - monocot cambium, $d v b$ - developing amphivasal vascular bundle, $m v b$ - mature amphivasal vascular bundle, $x$ - xylem (tracheids) of the amphivasal bundle

\section{Regulation of Cambial Growth}

Information about the control of this meristem at the genetic level is, to the best of our knowledge, lacking in the literature. However, some data on the hormonal and gravity induced adjustments of the meristem are available. A preliminary examination of Cordyline plants indicated that this was a difficult material for investigating the influence of hormones on the cambial activity because (a) the plants do not form annual growth rings, making it difficult to measure the amount of new accumulation of the secondary tissue produced after the treatment of the meristem with growth regulators, (b) the growth rate of this plant is much slower than one of the dicotyledonous twigs and, therefore, the experiments with growth regulators take much longer and are more prone to the risk of tissue infection (Fisher \& Tomlinson, 1972; Fisher, 1973). However, it has been shown that the activity of the meristem responsible for the secondary growth of the monocotyledons is more stimulated by the application of naphthalenacetic acid (NAA) than by that of benzyl adenine (BA) or gibberellic acid (GA) alone (Fisher, 1973). Other experiments carried out with this species revealed that the concentration of auxin in horizontal stems was up to seven times greater in the lower side of the stem axis than in the upper one (Fisher et al., 1974). The information available on biosythesis, transport and signaling of auxin in monocotyledons is based 
on the research conducted with maize and rice (reviewed by McSteen, 2010). These plants are considered not to be susceptible to auxin during the vascular differentiation, compared with the dicotyledons (Aloni \& Plotkin, 1985). Further factors co-acting with auxin are probably required for setting the process in (Scarpella \& Meijer, 2004). It is also assumed that the mechanism responsible for auxin metabolism, its movement and transduction is conserved in both monocotyledons and dicotyledons (McSteen, 2010).

In the horizontal or leaning monocot stems, the monocot cambium produces secondary tissues that are asymmetrically distributed (Fig. 3). As in the conifers, enhanced deposition of secondary tissues takes place on the lower side of the stem, but as opposed to the conifers, without association of the modified tracheids (Tomlinson \& Zimmermann, 1969; Fisher, 1975). The lack of anatomical changes characteristic of reaction wood indicates that the eccentric growth in these plants does not result in restoring leaning stem to vertical position, unlike the stem reaction wood in conifers, Ginkgo and most of the dicotyledonous plants (possessing compression and tension wood, respectively). This function is probably taken over by the region of primary growth (Tomlinson \& Zimmermann, 1969; Fisher, 1975). Then, the significance of the growth eccentricity is rather connected only with stabilization of the dislocated stem, like in Cycas with successive cambia (Fisher \& Marler, 2006; Altaner et al., 2010). The effect of the leaning position of the stem on the amount of secondary tissues deposited on the lower side is not uniform. Some species, e.g. Beaucarnea recurvata, $Y$. elephantipes and D. reflexa have shown strong eccentricity of secondary growth, possibly due to intensive cambial activity, in contrast to some others like $C$. terminalis or D. fragrans (Fisher, 1975).

The minimum night temperatures, transplanting of plants or the insect infestation may affect the activity of the vascular cambium (Fisher, 1975), resulting in appearance of ring-like structures in the secondary body of monocotyledonous plants (Fig. 3). The alternating 'dark' and 'light' zones in the secondary body, reported in early studies of

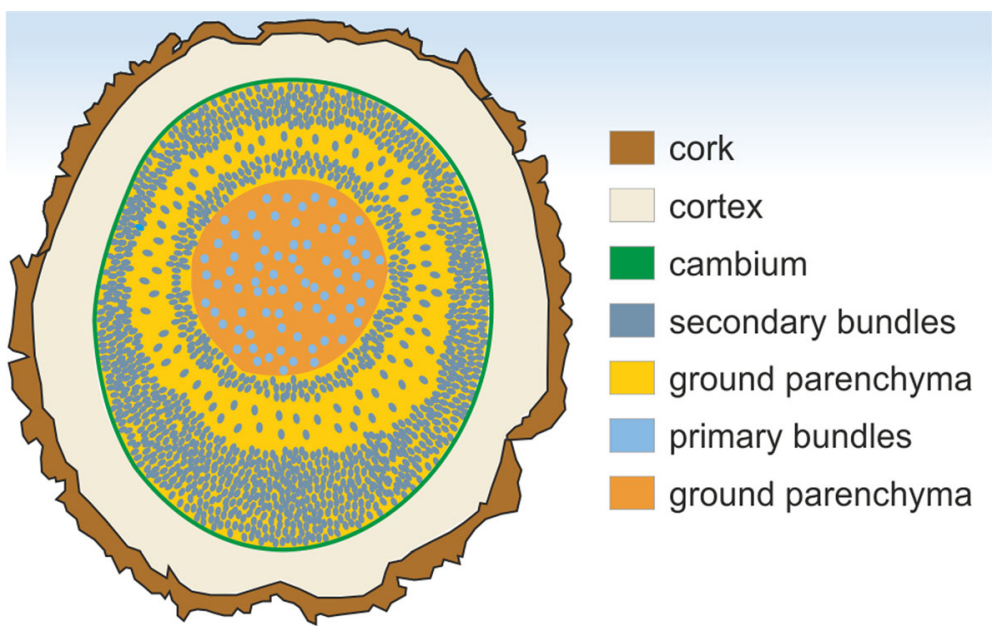

Fig. 3 Scheme of the eccentric secondary growth with 'growth rings' in stem of Cordyline terminalis. The ground parenchyma of the primary and secondary origin is marked with different colors (Jura-Morawiec \& Tulik, 2010; modified) 
monocotyledons (Lindinger, 1909), has been described later in a number of species like Aloe ferox (Chamberlain, 1921), Y. aloifolia (Barkley, 1924), B. recurvata and C. terminalis (Fisher, 1975), and Protoyucca shadishii, the first reported permineralized monocotyledon with secondary growth (Tidwell \& Parker, 1990). The concentric layers of the secondary tissue were referred to as 'growth rings' (Cheadle, 1937), as they look like annual growth rings of woody conifers and dicotyledons to the naked eye (LevYadun \& Lipschitz, 1986). However, there is no evidence that they correspond to yearly increments. The characteristic alternate zones in the secondary plant body appear due to differences in the size of vascular bundles, relative number of bundles per unit area, wall thickness of parenchyma cells and the size and abundance of parenchyma cells (Cheadle, 1937). In general, the vascular bundles are a little larger and less numerous per unit area, whereas parenchyma cells are unlignified in the 'light' zones, in contrast to the bundles and parenchyma in the 'dark' zones.

\section{Cambial Derivatives}

The monocot secondary meristem produces most of the derivatives inner to the cambial cylinder with both the secondary phloem and secondary xylem lying on one side, which makes the growth essentially unidirectional (Philipson \& Ward, 1965). The parenchymatous secondary conjunctive tissue is deposited both on the internal and external sides; the deposition may be meager as in Dasylirion serratifolium or massive as in Furcraea pubescens (Schoute, 1903; Cheadle, 1937). The cells on the outer side of the monocot cambium undergo little differentiation; they enlarge about twice the size of the initial cambial cells, become filled with needle-shaped crystals of calcium oxalate, and their walls do not thicken much (Tomlinson \& Zimmermann, 1969). More crystals accumulate in the secondary tissue than in the primary one (Lu \& Chiang, 1976).

The inner derivatives of the monocot cambium differentiate into cells of secondary conjunctive tissue and vascular bundles. The secondary parenchyma possesses large intercellular spaces, with its component cells often arranged in radial files. The parenchyma cells adjacent to vascular bundles have considerably thickened walls with distinctly visible pits (Barkley, 1924). The other derivatives divide rapidly and differentiate into xylem and phloem cells, which constitute the entire vascular bundles (desmogen strands) (Stevenson \& Fisher, 1980). The xylem contained only tracheids with thick walls and circular bordered pits (Carlquist, 2012). These tracheids are about 20 times (Waterhouse, 1987) longer than the cambial cells they derive from. This is largely because of the enormous intrusive growth experienced by the developing tracheids during differentiation. The other cells of the secondary tissue are comparable in length with their initials. The phloem strand is composed of sieve elements and companion cells. Barkley (1924) reported 6-8 sieve tubes with companion cells in the phloem of $Y$. aloifolia, as seen in the transverse section. The constituent cells of the conjunctive tissue may exhibit radial alignment, as does the arrangement of vascular bundles (Stevenson, 1980).

Secondary vascular bundles usually differ from primary bundles in having the amphivasal arrangement of xylem and phloem (xylem surrounding the phloem), whereas the latter usually have a collateral arrangement (Tomlinson \& Zimmemann, 1969; Jura-Morawiec \& Wiland-Szymańska, 2014). Studies on Yucca spp. suggest that 
the pattern of vascular system is species-specific. In the stem of $Y$. aloifolia the collateral as well as the amphivasal secondary vascular bundles were distinguished (Barkley, 1924). In contrast, these bundles were only amphivasal in Y. whipplei (Diggle \& DeMason, 1983a, b) and only collateral in Y. brevifolia (Carlquist, 2012). It is known that the xylem and phloem patterns within the vascular bundle are subjected to genetic control. The Class III HD-ZIP and KANADI genes, with antagonistic role, are critical for determining the pattern of xylem and phloem within the vascular bundle (Emery et al., 2003). Most research in this field has been done with the dicot model plant A. thaliana. However, it is hypothesized that these genes are involved in more general patterning system that appeared early in or prior to the land-plant evolution (Floyd \& Bowman, 2007), and hence are good genetic markers for understanding the morphological and developmental innovations achieved during the evolutionary history of land plants. Research on the Class III Homeodomain Leucine Zipper gene family members in rice has partly confirmed that they have conserved functions with their homologs in A. thaliana (Itoh et al., 2008). The interaction of the class III HD-ZIP/KANADI genes in the stem of monocots with secondary growth remains unexplained so far, although it has provided an interesting direction for future work (Dinneny \& Yanofsky, 2004).

The functional role of the secondary plant body is connected with the mechanical support and the storage of food or water (Cordemoy, 1893; Holm, 1894; Lindinger, 1909). The hard lignified ring of the secondary ground parenchyma may play supportive function (e.g. Dracaena), whereas unlignified ground parenchyma takes part in food storage (e.g. Yucca). In desert species (e.g. Beaucarnea) secondary tissues can maximize the availability of water.

Based on a single report concerning $D$. mannii, it is known that despite exhibiting different anatomical features the monocot secondary tissues possess mechanical properties comparable with those of the dicotyledonous wood of similar density; the difference is confined only to the extent of the radial and tangential shrinkage (Torelli \& Trajković, 2003).

\section{The Secondary Meristem for Protective Tissue Formation}

As mentioned above in the section 'Terminology', the meristem that gives rise to the secondary protective tissue in monocots is rarely distinguished from derivatives in normal description. Therefore, the general designation of the secondary protective tissue, i.e. storied cork, refers to both the meristem and its derivative cells. The presence/absence of this tissue is considered as a diagnostic trait (Tenorio et al., 2012).

In general, meristematic cells arise from some parenchyma cells in the peripheral layers of the cortex (subepidermis) that undergo dedifferentiation and start to divide periclinally (Fig. 4a, b). The meristematic cells are distributed among undivided cortical cells and do not form a continuous layer (Schoute, 1902) characteristic of a typical phellogen (Junikka, 1994; Waisel, 1995). Moreover, these initials have a limited divisional activity (Esau 1965). Thus the arrangement of cells in the storied cork might be more or less regular. Krauss (1949) pointed out that sometimes divisions of isolated initials give rise to irregularly placed groups of cells (Fig. 4c). However, in some cases the cell arrangement pattern can be regular, suggestive to the presence of a cork, like one formed by the phellogen in conifers and dicotyledons, when a number of laterally 

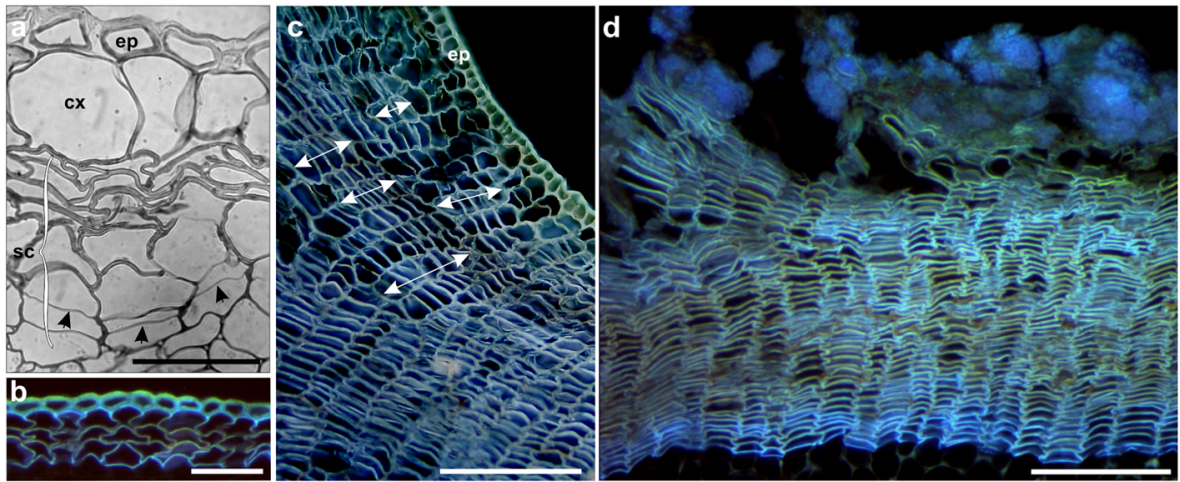

Fig. 4 Structural details of Dracaena protective tissues: transverse sections from the epon- a and waxembedded b-d materials. Bright field and the autofluorescence induced by UV light. a $D$. draco; early stages in development of secondary protective tissue, periclinal divisions of meristematic cells were highlighted with arrows, $s c$ - storied cork, ep - epidermis, $c x$ - cortex. b D. marginata, arrangement of cork cells in young stem. c, $\mathbf{d}$ D. fragrans, storied cork with groups of cells marked with arrows c, 'rhytidome'-like zone d. Scale bars: a, b $100 \mu \mathrm{m} ; \mathrm{c}, \mathrm{d} 200 \mu \mathrm{m}$

adjacent cells undergo divisions. Contrary to the phellogen of conifers and dicots, the meristem deposits only one type of derivatives i.e. cork cells, the phelloderm is absent. During the course of their differentiation there probably occur the cell wall apposition with suberin and incrustation by lignin, followed by the programmed cell death, suggesting the existence of the same stages of development as in the cork cells of other plants (Krishnamurthy et al., 2000).

In the non-monocot woody plants, the epidermis subjected to pressure due to meristematic activity of vascular cambium is completely replaced by the periderm. The monocotyledons do not develop a type of periderm like that of dicotyledons or conifers (Weisse, 1897; Philipp, 1923). Sometimes, even in older individuals as in D. fragrans for instance, both the modified epidermal cells of primary origin and the storied cork are considered to fulfill the role of the protective tissue (Jura-Morawiec \& Tulik, 2013). The epidermal cells possess thick and lignified tangential and radial walls as well as the outer tangential walls covered by cutin like-deposition (Fig. 4c).

In the anatomical/botanical sense the rhytidome (successive periderms interspersed with the non-conducting phloem) does not exist in the woody monocots, but the successive layers of the cork are separated by suberized undivided cortical cells (Philipp, 1923). Thus, it makes the whole structure similar to the rhytidome of conifers and dicots in appearance (Fig. 4d).

\section{Conclusion}

The two meristematic tissues responsible for the secondary growth in the monocot species differ from the vascular cambium and the cork cambium of conifers and dicotyledons. The history of research in this field dates back to 19th century; however, these meristems could not draw enough attention of researches, resulting eventually in a lopsided understanding of the monocot secondary meristems in comparison to those typical for most vascular plants. In consequence, we are still stuck with (a) 
terminological discrepancy regarding the cellular organization of the meristems taking part in the secondary increment, that can be misleading and (b) incomplete basic knowledge gained by using the traditional tools. So far no quantitative studies and critical analyses at the genetic level have been undertaken with reference to secondary growth in the monocot species. This review is believed to stimulate new research on the understudied phenomena of the monocot secondary meristems and their derivatves so as to produce a comprehensive account and a complete picture of the intricacies involved.

Open Access This article is distributed under the terms of the Creative Commons Attribution License which permits any use, distribution, and reproduction in any medium, provided the original author(s) and the source are credited.

\section{Literature Cited}

Aloni, R. \& T. Plotkin. 1985. Wound induced and naturally occurring regenerative differentiation of xylem in Zea mays. Planta 163: 126-132.

Altaner, C. M., M. C. Jarvis, J. B. Fisher \& T. E. Marler. 2010. Molecular xylem cell wall structure of an inclined Cycas micronesica stem, a tropical gymnosperm. IAWA Journal 31: 3-11.

Arber, A. 1925. Monocotyledons: A morphological study. Cambridge University Press, Cambridge.

Bailey, I. W. 1923. The cambium and its derivative tissues. IV. The increase in girth of the cambium. American Journal of Botany 10: 499-509.

Barkley, G. 1924. Secondary stellar structure of Yucca. Botanical Gazette 78: 433-439.

Beck, C. B. 2010. An introduction to plant structure and development, ed. 2nd. Cambridge University Press, Cambridge.

Carlquist, S. 2012. Monocot xylem revisited: New information, new paradigms. Botanical Review 78: 87153.

Chakroun, S. \& C. H. Hébant. 1983. Developmental anatomy of Aphyllanthes monspeliensis, a herbaceous monocotyledon with secondary growth. Plant Systematics and Evolution 141: 231-241.

Chamberlain, C. 1921. Growth rings in monocotyledons. Botanical Gazette 72: 293-304.

Cheadle, V. I. 1937. Secondary growth by means of a thickening ring in certain monocotyledons. Botanical Gazette 98: 535-555.

Clowes, F. A. L. 1961. Apical meristems. Blackwell Scientific Publ, Oxford.

Cordemoy, H. J. 1893. Sur le rôle des tissues secondaires à réserves des Monocotylédones arborescentes. Comptes Rendus de l'Académie des Sciences 117: 132-134.

DeMason, D. A. 1994. Stem thickening in monocotyledons. Pp 288-310. In: M. Iqbal (ed). Growth Patterns in Vascular Plants. Dioscorides Press, Portland, Oregon.

\& P. K. Diggle. 1984. The relationship between the primary thickening meristem and the secondary thickening meristem in Yucca whipplei Torr. III. Observations from histochemistry and audiography. American Journal of Botany 71: 1260-1267.

\& M. A. Wilson. 1985. The continuity of primary and secondary growth in Cordyline terminalis (Agavaceae). Canadian Journal of Botany 63: 1907-1913.

den Outer, R. W. 1986. Storied structure of the secondary phloem. IAWA Bulletin 7: 47-51.

Diggle, D. K. \& D. A. DeMason. 1983a. The relationship between the primary thickening meristem and the secondary thickening meristem in Yucca whipplei Torr. I. Histology of the mature vegetative stem. American Journal of Botany 70: 1195-1204.

\& - 1983b. The relationship between the primary thickening meristem and the secondary thickening meristem in Yucca whipplei Torr. II. Ontogenetic relationship within the vegetative stem. American Journal of Botany 70: 1205-1216.

Dinneny, J. R. \& M. F. Yanofsky. 2004. Vascular pattering: Xylem or phloem? Current Biology 14: 112-114.

Donoghue, M. J. 2005. Key innovations, convergence, and success: Macroevolutionary lessons from plant phylogeny. Paleobiology 31: 77-93. 
Emery, J. F., S. K. Floyd, J. Alvarez, Y. Eshed, N. P. Hawker, A. Izhaki, S. F. Baum \& J. L. Bowman. 2003. Radial pattering of Arabidopsis shoots by class III HD-ZIP and KANADI genes. Current Biology 13: 1768-1774.

Esau, K. 1965. Plant anatomy, ed. 2nd. John Wiley and Sons, New York.

Evert, R. 2006. Esau's Plant anatomy: Meristems, cells, and tissues of the plant body: their structure, function, and development. John Wiley and Sons, New York.

Fahn, A. 1967. Plant anatomy. Pergamon, Oxford.

Fisher, J. B. 1973. The monocotyledons: Their evolution and comparative biology II. Control of growth and development on the monocotyledons - new areas of experimental research. Quarterly Review of Biology 48: 291-298.

1975. Eccentric secondary growth in Cordyline and other Agavaceae (Monocotyledonae) and its correlation with auxin distribution. American Journal of Botany 62: 292-302.

_ \& T. E. Marler. 2006. Eccentric secondary growth but no compression wood in a horizontal stem of Cycas micronesica (Cycadales). IAWA Journal 27: 377-382.

\& P. B. Tomlinson. 1972. Morphological studies in Cordyline (Agavaceae). II. Vegetative morphology of Cordyline terminalis. Journal of the Arnold Arboretum 53: 113-127.

- S. P. Burg \& B. G. Kang. 1974. Relationship of auxin transport to branch dimorphism in Cordyline, a woody monocotyledon. Physiologia Plantarum 31: 284-287.

Floyd, S. K. \& J. L. Bowman. 2007. The ancestral developmental tool kit of land plants. International Journal of Plant Science 168: 1-35.

French, J. C. \& P. B. Tomlinson. 1981. Vascular patterns in stems of araceae: Subfamily pothoideae. American Journal of Botany 68: 713-729.

Holm, T. 1894. The function of the secondary tissues in arborescent monocotyledons. Botanical Gazette 19: 66-67.

IAWA Committee on Nomenclature 1989. IAWA List of microscopic features for hardwood identification. IAWA Bulletin n.s.10:219-332.

Itoh, J. I., K. I. Hibara, Y. Sato \& Y. Nagato. 2008. Developmental role and auxin responsiveness of class III homeodomain leucine zipper gene family members in rice. Plant Physiology 147: 1960-1975.

IUCN2014. The IUCN Red List of Threatened Species. Version 2014.1. http://www.iucnredlist.org.

Junikka, L. 1994. Survey of english macroscopic bark terminology. IAWA Journal 15: 3-45.

Jura-Morawiec, J. \& M. Tulik. 2013. Stem protective tissue in Dracaena species: A preliminary study. Proceedings of the International Conference on Functional Plant Anatomy, Moscow, Russia, p 92. \& - 2010. Stem structure of monocotyledonous trees. Sylwan 154: 755-763 (in Polish).

\& J. Wiland-Szymańska. 2014. A novel insight into the structure of amphivasal secondary bundles on the example of Dracaena draco L. stem. Trees 28: 871-877.

Krauss, B. H. 1949. Anatomy of the vegetative organs of the pineapple Ananas comosus (L.) Merr. III. The root and the cork. Botanical Gazette 110: 550-587.

Krishnamurthy, K. V., R. Krishnaraj, R. Chozhavendan \& F. S. Christopher. 2000. The programme of cell death in plants and animals. Current Science 79: 1169-1181.

Lev-Yadun, S. \& N. Liphschitz. 1986. Growth ring terminology - some proposals. IAWA Bulletin 7: 72.

Lindinger, L. 1909. Jahresringe bei den Monokotylen der Drachenbaumform. Naturwissenschaftliche Wochenschrift (N.F.) 8: 491-494.

Lu, C. H. \& S. Chiang. 1976. Lateral thickening in the stem of Agave rigida Mill. and Aloe vera L. Taiwania 21: 204-219.

Majumdar, G. P. 1941. The sliding, gliding, symplastic or the intrusive growth of the cambium cells and their derivatives in higher vascular plants. Journal of Indian Botanical Society 20: 161-171.

McSteen, P. 2010. Auxin and monocot development. Cold Spring Harbor Perspectives in Biology 2: a001479. doi:10.1101/cshperspect.a001479.

Philipp, M. 1923. Über die verkorkten Abschlußgewebe der Monokotylen. Bibliotheca Botanika Stuttgart 92: $1-27$.

Philipson, W. R. \& J. M. Ward. 1965. The ontogeny of the vascular cambium in the stem of seed plants. Biological Reviews 40: 534-579.

\& B. G. Butterfield. 1971. The vascular cambium: Its Development and Activity. Chapman and Hall Ltd., London.

Ramos, M., M. Rocheta, L. Carvalho, V. Inacio, J. Graca \& L. Morais-Cecilio. 2013. Expression of DNA methyltransferases is involved in Quercus suber cork quality. Tree Genetic and Genomes 9: 1481-1492.

Rastogi, V. B. 2009. A complete course in ISC biology. Pitambar Publishing Company (P) Ltd.

Rudall, P. 1991. Lateral meristems and stem thickening growth in monocotyledons. Botanical Review 57: $150-163$. 
1995. New records on secondary thickening in monocotyledons. IAWA Journal 16: 261-268.

Scarpella, E. \& A. H. Meijer. 2004. Pattern formation in the vascular system of monocot and dicot plant species. New Phytologist 164: 209-242.

Schoute, J. C. 1902. Über Zellteilungsvorgänge in Cambium. Verhandelingen der Koninklijke Akademie van Wetenschappen, Afdeeling Natuurkunde 9: 1-59.

1903. Die Stammesbildung der Monokotylen. Flora 92: 32-48.

Scott, D. H. \& G. Brebner. 1893. On the secondary tissues in certain monocotyledons. Annals of Botany 7: $22-62$.

Seberg, O. G., J. I. Petersen, J. C. Davis, J. C. Pires, D. W. Stevenson, M. W. Chase, M. F. Fay, D. S. Devey, T. Jorgensen, K. J. Sytsma \& Y. Pillon. 2012. Phylogeny of the Asparagales based on three plastid and two mitochondrial genes. American Journal of Botany 99: 875-889.

Stevenson, D. W. 1980. Radial growth in Beaucarnea recurvata. American Journal of Botany 67: 476-489.

\& J. B. Fisher. 1980. The developmental relationship between primary and secondary thickening growth in Cordyline (Agavaceae). Botanical Gazette 141: 264-268.

Stone, B. C. 1970. Morphological studies in Pandanaceae. II. The "coniferoid" habit in Pandanus sect. Acanthostyla. Bulletin of the Torrey Botanical Club 97: 144-149.

Tenorio, V., C. M. Sakuragui \& R. C. Vieira. 2012. Stem anatomy of Philodendron Scholl (Arecaceae) and its contribution to the systematics of the genus. Plant Systematics and Evolution 298: 1337-1347.

Tidwell, D. \& L. R. Parker. 1990. Protoyucca shadishii gen. et sp. nov., an arborescent monocotyledon with secondary growth from the Middle Miocene of Northwestern Nevada, U.S.A. Review of Palaeobotany and Palynology 62: 79-95.

Tomlinson, P. B. 1961. Anatomy of monocotyledons. Vol. 2 Palmae. Oxford University Press.

\& M. H. Zimmermann. 1967. The "wood" of monocotyledons. IAWA Bulletin 2: 4-24.

$\boldsymbol{\&}-1969$. Vascular anatomy of monocotyledons with secondary growth - an introduction. Journal of the Arnold Arboretum 50: 159-179.

Torelli, N. \& J. Trajković. 2003. Dracaena mannii Baker - physical, mechanical and related properties. Holz als Roh- und Werkstoff 6: 477-478.

Treesubsuntorn, C. \& P. Thiravetyan. 2012. Removal of benzene from indoor air by Dracaena sanderiana: Effect of wax and stomata. Atmospheric Environment 57: 317-321.

Ursache, R., K. Neminen \& Y. Helariutta. 2012. Genetic and hormonal regulation of cambial development. Physiologia Plantarum 147: 36-45.

Verma, N. \& R. L. Khosa. 2012. Development of standardization parameters of Costus speciosus rhizomes with special reference to its pharmacognostical and HTPLC studies. Asian Pacific Journal of Tropical Biomedicine 2: S276-S283.

Waisel, Y. 1995. Developmental and functional aspects of the periderm. Pp 293-315. In: M. Iqbal (ed). The cambial derivatives. Gebruder Borntraeger, Berlin, Stuttgart, Germany.

Waterhouse, J. T. 1987. The phylogenetic significance of Dracaena - type growth. Proceeding of the Linnean Society of New South Wales 109: 129-138.

Weisse, A. 1897. Ueber Lenticellen und verwandte Durchlüftungseinrichtungen bei Monocotylen. Berichte der Deutschen Botanischen Gesellschaft 15: 303-320.

Wolverton, B.C., Johnson, A., \& K. Bounds. 1989. Interior landscape plants for indoor air pollution abatement. NASA/ALCA Final Report, Plants for Clean Air Council, Davidsonville, Maryland, USA.

Zimmermann, M. H. \& P. B. Tomlinson. 1970. The vascular system in the axis of Dracaena fragrans (Agavaceae). Distribution of and development of secondary vascular tissue. Journal of the Arnold Arboretum 51: 478-491. $\&-$. 1972. The vascular system of monocotyledons stem. Botanical Gazette 133: 141-155. 